\title{
The Relationship Between Satisfaction with Complaint Handling and Repurchase Intentions: Detecting Moderating Influences in E-Tail
}

\author{
Mateus Nagel ${ }^{\dagger}$ \\ Faculdade Integrada de Santa Maria \\ Cristiane Pizzutti dos Santos $\Omega$ \\ Universidade Federal do Rio Grande do Sul (UFRGS)
}

\begin{abstract}
This paper examines which factors affect the relationship between consumers' satisfaction with complaint handling and repurchase intentions. We present a conceptual framework that explains why satisfaction with complaint handling (SATCOM) does not necessary lead to repurchase intention (RI) for online shoppers. The authors test five moderating variables of the relationship between SATCOM and RI: relationship quality (relational factor), economic value, alternative attractiveness (marketplace factor), inferred motives and stability of the failure (failure-related factors). To test our hypotheses, we conducted an online survey with e-shoppers and used moderated regression analysis and a bootstrapping procedure. The findings show that all moderators help to explain the nonlinearity between SATCOM and RI. Hence, this study makes theoretical and managerial contributions related to failures in shopping experiences and repurchase intentions in e-tail.
\end{abstract}

Keywords: E-commerce, Satisfaction with complaint handling, Repurchase intention.

\section{INTRODUCTION}

Global business-to-consumer (B2C) e-commerce sales will rise from USD 1.67 trillion in 2015 to USD 3.57 trillion by 2019 (EMARKETER, 2016). Despite the prominent development of e-commerce, the number of complaints posted by e-consumers on websites indicates that service failures are frequent and even an inherent part of e-tail. Thus, researchers have emphasized the importance of understanding how businesses can restore customer satisfaction after service failures through recovery processes in brick-and-mortar (ORSINGHER et al., 2010) and online (PIZZUTTI; FERNANDES, 2010) environments and how important post-recovery satisfaction is in avoiding consumer exits.

Based on critical incidents, Holloway and Beatty (2003) found that some consumers continue to make purchases on a retailer's website, even if they were dissatisfied with its recovery attempt, showing that sometimes the relationship between consumers' satisfaction with complaint handling (SATCOM) and their repurchase intentions (RI) is not in accordance with the 'expected standard', i.e., the greater a consumer's post-recovery satisfaction, the greater his/her consumer RI. However, the authors did not explore the reasons for this phenomenon.

Corresponding author:

${ }^{\dagger}$ Faculdade Integrada de Santa Maria.

E-mail: mateusbnagel@gmail.com

$\Omega$ Universidade Federal do Rio Grande do Sul (UFRGS).

E-mail: crispizzutti@gmail.com

Received: 03/03/2016. Revised: 08/06/2016.

Accepted: 08/06/2016.

Published Online: 07/01/2017.

DOI: http://dx.doi.org/10.15728/bbr.2017.14.5.4 
Our paper addresses this topic by answering the following research question: which factors affect the relationship between consumers' SATCOM and RI?

Prior empirical research demonstrates that the conversion of satisfaction into repurchase intentions may be moderated by various factors, such as age and income, or the duration of the relationship (SEIDERS et al., 2005); trust and perceived value (ANDERSON; SRINIVASAN, 2003); and switching costs (JONES et al., 2002). However, despite studies that have examined the impact of consumers' initial satisfaction (i.e., satisfaction resulting from the comparison between consumers' expectations and post-purchase performance) (ANDREASEN, 1977) on their repurchase intentions using moderating variables, the moderators in the relationship between SATCOM and RI have been neglected.

Additionally, few studies have explored the relationship between SATCOM and loyalty regarding websites. Therefore, to answer our research question, we propose five moderating variables: one relational factor, relationship quality; two marketplace factors, economic value and alternative attractiveness; and two failure-related factors, inferred motives and failure stability. We categorized them in these three factors based on Seiders et al. (2005) and on Holloway and Wang (2015). The first authors categorized the moderators of the relationship between satisfaction and repurchase in three types: customer, relational and marketplace factors; and the last authors rank moderators involving service failures and recovery process in three categories: consumer-firm relationship; individual and contextual variables. Based on these two studies, we decided to explore relational (presented in both studies), marketplace (from Seiders et al. study) and failure-related factors (from Holloway and Wang's work). We do not focus on the individual factor, because there is a number of studies exploring the moderating role of individual variables (e.g. HOMBURG; GIERING, 2001; SEIDERS et al. 2005) and also because they are more difficult to be controlled by the companies. Moreover, the variables we chose in each category have theoretical and practical relevance in online and failure contexts, but they have not been fully explored as moderators in the marketing literature.

The main contribution of this study is it stance that an e-tail must not only address consumer complaints correctly but also be mindful that other contingent factors (i.e perception of failure stability and previous experience with the website) may play a critical role as boundary conditions for the impact of consumer SATCOM on loyalty.

\section{CONCEPTUAL FRAMEWORK AND HYPOTHESES}

In Figure 1, we present a conceptual framework that proposes that the relationship between SATCOM and RI may be explained by relational, marketplace and failure-related moderators. We conceptualize customer SATCOM as a customer's evaluation of a company's recovery efforts to solve a problem (TAX et al., 1998), whereas RI represents the customer's self-reported likelihood of engaging in future repurchase behavior (SIRDESHMUKH et al., 2002).

The dotted lines in Figure 1 capture direct relationships that have been previously established in the literature and that are not the focus of the present research. Relational factors (e.g. trust, commitment, satisfaction, and type of relationship) have already been tested to explain consumer loyalty in different contexts, such as; to online retail websites (e.g. KEATING et al. 2011), to online auction (e.g. SUN 2010), to self-service-technologies (e.g. WANG et al., 2012). Particularly regarding service failures and recovery, Hess (2008) showed that firm reputation help explain passengers repurchase intention after service failures. Likewise, Pizzutti and Fernandes (2008, 2010) found that trust is a relevant antecedent of repurchase intentions after recovery efforts in offline and online retails.

On the direct effect of failure related-variables, the impact of failure stability on repurchase intentions have already been evidenced by Blodgett (1994). Hess (2008) also 
BBR

14,3

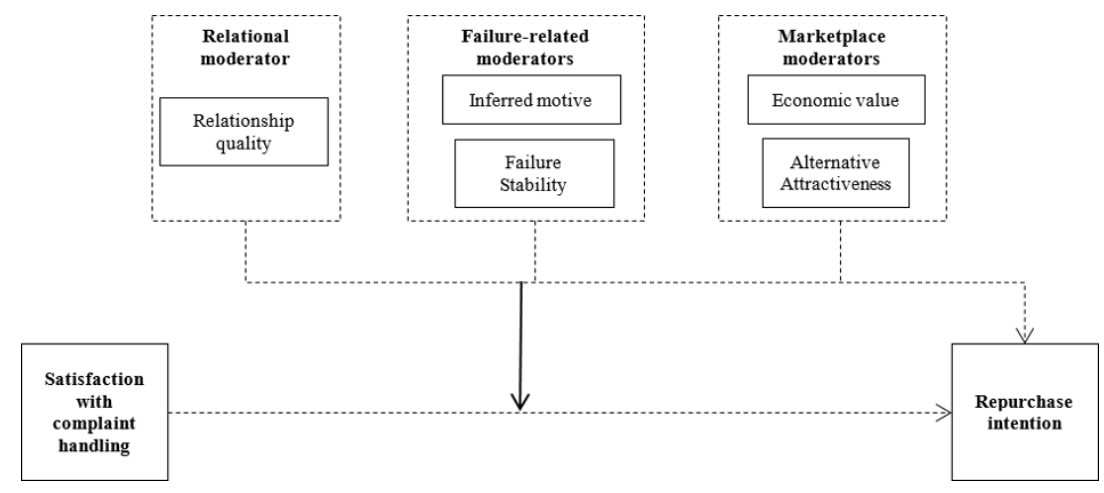

Figure 1. Framework for understanding the impact of proposed moderators on the relationship between SATCOM and RI in e-tail

Source: Elaborated by the authors

found that attributions of controllability and stability impact negatively on customer repurchase intention, and Smith and Bolton (1998) showed that customers' repatronage intentions are lower when they believe that failure is likely to happen again. Besides, Joireman et al. (2013) showed that depending on the valence of the reasons given by the company in relation to failure situations (i.e. inferred motives), consumers will continue to patronage from the same retailer.

Lastly, marketplace characteristics (e.g. economic value and alternative attractiveness) have been tested to explain repurchase intentions for websites (JIANG; ROSEMBLOOM), and for service providers (JONES et al., 2000). Nevertheless, the potential role of these variables related to failure, marketplace, and relational aspects have not been tested as moderators between SATCOM and RI (see Table 1), with few exceptions: for example, Matilla (2004) who found that affective commitment moderates the relationship between post-failure attitude and loyalty intentions for restaurant customers, and Holloway et al (2005) who showed that the effect of SATCOM on RI was higher for consumers with high experience in online purchasing in general than for those with low online purchasing experience.

As we can see from Table 1, the default expectation is that SATCOM positively influences RI. We offer no formal hypothesis for this well-established relationship or for the other direct relationships. Instead, we focus on the moderating effects depicted by the solid line in Figure 1. We predict that relational, marketplace and failure-related characteristics moderate the relationship between SATCOM and RI in the online context.

These factors, whose potential role as moderators of the relationship between SATCOM and RI have been neglected by marketing literature, include the following: relationship quality, inferred motive by the customer, failure stability, economic value and attractiveness of the competitors. We selected these variables for some reasons: 1) they have theoretical relevance that have already been explored by the marketing literature in contexts other than the post-recovery context; 2) there are sound scales in the literature to measure them; 3 ) there is still little work on their roles as moderators; and 4) all the variables may be at least partially shaped or modified by companies' actions, which has important managerial implications.

\subsection{RELATIONAL FACTOR: RELATIONSHIP QUALITY}

Relationship quality (RQ) involves the quality of interactions between company and customers, interpreted by the cumulative value of this relationship (GUMESSON, 1987). Following Grégoire and Fisher (2008), we measure this construct through three dimensions: satisfaction, trust and commitment. 
Table 1. Empirical studies on SATCOM and RI

\begin{tabular}{|c|c|c|c|c|}
\hline Authors & Independent variable & Moderator & Dependent variable & Findings \\
\hline $\begin{array}{l}\text { Martin; Smart } \\
(1994)\end{array}$ & $\begin{array}{l}\text { Satisfaction with the } \\
\text { complaint handling } \\
\text { (SATCOM) }\end{array}$ & - & Repurchase propensity & $\begin{array}{l}\text { Consumer SATCOM impacted on } \\
\text { repurchase propensity. }\end{array}$ \\
\hline $\begin{array}{l}\text { Gilly; Gelb } \\
(1982)\end{array}$ & $\begin{array}{l}\text { Satisfaction with } \\
\text { organizational complaint } \\
\text { response; satisfaction with } \\
\text { complaint response }\end{array}$ & - & Brand repurchase & $\begin{array}{l}\text { Consumer satisfaction with } \\
\text { organizational complaint response } \\
\text { predicted brand repurchase. }\end{array}$ \\
\hline Gilly (1987) & SATCOM & - & Repurchase intentions (RI) & $\begin{array}{l}\text { SATCOM influenced repurchase } \\
\text { intentions. }\end{array}$ \\
\hline $\begin{array}{l}\text { Spreng et al. } \\
(1995)\end{array}$ & Overall SATCOM & - & RI & $\begin{array}{l}\text { The overall SATCOM influenced } \\
\text { positively their repurchase intention. }\end{array}$ \\
\hline $\begin{array}{l}\text { Conlon; } \\
\text { Murray (1996) }\end{array}$ & $\begin{array}{l}\text { Satisfaction with the speed } \\
\text { of reply }\end{array}$ & - & $\begin{array}{l}\text { Likelihood of future } \\
\text { business with the company }\end{array}$ & $\begin{array}{l}\text { The consumers' satisfaction with } \\
\text { the speed of the reply influenced the } \\
\text { likelihood of future business with the } \\
\text { company. }\end{array}$ \\
\hline $\begin{array}{l}\text { Dube; Maute } \\
\text { (1998) }\end{array}$ & $\begin{array}{l}\text { Value-recovery (complaint- } \\
\text { management) }\end{array}$ & $\begin{array}{l}\text { Competitive } \\
\text { environment }\end{array}$ & Satisfaction, loyalty. & $\begin{array}{l}\text { Value-recovery influenced consumer } \\
\text { loyalty. Competition environment did } \\
\text { not moderate the relationship between } \\
\text { value-recovery and satisfaction. } \\
\text { Besides, satisfaction mediated the } \\
\text { relationship between value-recovery } \\
\text { and situational loyalty and enduring } \\
\text { loyalty. }\end{array}$ \\
\hline $\begin{array}{l}\text { Webster; } \\
\text { Sundaram } \\
(1998)\end{array}$ & Failure recovery effort & - & Satisfaction, loyalty. & $\begin{array}{l}\text { The firm recovery efforts impacted } \\
\text { customer SATCOM and loyalty. }\end{array}$ \\
\hline $\begin{array}{l}\text { Smith; Bolton } \\
\text { (1998) }\end{array}$ & $\begin{array}{l}\text { Stability attributions; prior } \\
\text { repatronage intentions; } \\
\text { SATCOM }\end{array}$ & - & $\begin{array}{l}\text { Repatronage intention; } \\
\text { cumulative satisfaction }\end{array}$ & $\begin{array}{l}\text { Cumulative satisfaction of consumers' } \\
\text { e their repatronage intentions were } \\
\text { lower when they believed that failure } \\
\text { was likely to happen again. Besides, } \\
\text { consumer's repatronage intentions } \\
\text { were higher when their cumulative } \\
\text { satisfaction was higher. }\end{array}$ \\
\hline $\begin{array}{l}\text { Davidow } \\
(2000)\end{array}$ & SATCOM & - & RI & Consumer SATCOM predicted RI. \\
\hline Matilla (2001) & $\begin{array}{l}\text { Service type; compensation; } \\
\text { magnitude of failure }\end{array}$ & - & $\begin{array}{l}\text { Loyalty; satisfaction with } \\
\text { recovery; interactional } \\
\text { justice; procedural justice; } \\
\text { distributive justice }\end{array}$ & $\begin{array}{l}\text { Effective service recovery (apology } \\
\text { with tangible compensation) increased } \\
\text { SATCOM, and also increased loyalty } \\
\text { ratings for hair stylist scenario, this } \\
\text { impact was lower for dry-cleaning and } \\
\text { restaurant services. }\end{array}$ \\
\hline $\begin{array}{l}\text { McColl- } \\
\text { Kennedy et al. } \\
(2003)\end{array}$ & $\begin{array}{l}\text { Allow voice; Display of } \\
\text { concern; Compensation; } \\
\text { Service provider gender }\end{array}$ & Gender & $\begin{array}{l}\text { Future intentions, } \\
\text { satisfaction, employee effort }\end{array}$ & $\begin{array}{l}\text { Consumers were more satisfied with } \\
\text { recovery when the outcome of the } \\
\text { compensation was high ( } 50 \% \text { rebat } \\
\text { on a night's stay), and then had more } \\
\text { future intentions with the company. } \\
\text { This impact was stronger for women } \\
\text { than for men when the service provider } \\
\text { was male compared when there was a } \\
\text { female service provider. }\end{array}$ \\
\hline $\begin{array}{l}\text { Mattila, Mount } \\
(2003)\end{array}$ & SATCOM & - & Repeat patronage & $\begin{array}{l}\text { SATCOM increases the probability of } \\
\text { repeat patronage. }\end{array}$ \\
\hline Matilla (2004) & Post-failure atittude & $\begin{array}{l}\text { Affective } \\
\text { commitment }\end{array}$ & Loyalty intentions & $\begin{array}{l}\text { Emotional bonding moderated } \\
\text { customer responses to service failures } \\
\text { and loyalty intentions. }\end{array}$ \\
\hline $\begin{array}{l}\text { Kim et al. } \\
(2004)\end{array}$ & SATCOM & - & Revisit intention & $\begin{array}{l}\text { SATCOM was positively associated } \\
\text { with revisit intention. }\end{array}$ \\
\hline
\end{tabular}

Gilly (1987)

Spreng et al. the speed of the reply influenced the company.
Dube; Maute Value-recovery (complaint(1998)

$$
\text { management) }
$$

Competitive environmen
Repatronage intention
Value-recovery influenced consumer loyalty. Competition environment did

Besides, satisfaction mediated the relationship between value-recovery loyalty.

Webster; Sundaram (1998) tability attributions; prior

SATCOM recovery; interactional

ice; procedural justice

distributive justice
SATCOM, and also increased loyalty ratings for hair stylist scenario, this restaurant services. ome of the on a night's stay), and then had more future intentions with the company.

impact was stronger for women wan for men when the service provider female service provider.$$
\text { repeat patronage. }
$$

Emotional bonding moderated OM was positively associated revisit intention. 


$\begin{array}{lc}\text { Holloway et al. } & \begin{array}{c}\text { Cumulative } \\ \text { online } \\ (2005)\end{array} \\ \text { purchasing } \\ \text { experience }\end{array}$

The effect of SATCOM on RI was

higher for consumers with high experience in online purchasing in general than for those with low online purchasing experience.

\begin{tabular}{|c|c|c|c|c|}
\hline $\begin{array}{l}\text { Harris et al. } \\
(2006)\end{array}$ & $\begin{array}{l}\text { Satisfaction with remedy } \\
\text { (satisfaction with service } \\
\text { failure recovery) }\end{array}$ & $\begin{array}{l}\text { Online/offline } \\
\text { environment; } \\
\text { type of service }\end{array}$ & Intention to return & $\begin{array}{l}\text { Recovery level had a positive impact } \\
\text { on RI, and this effect was greater } \\
\text { for offline than online environment. } \\
\text { Moreover, airline customers were more } \\
\text { satisfied and more likely to show loyal } \\
\text { behaviors than are bank customers. }\end{array}$ \\
\hline $\begin{array}{l}\text { Kau, Loh } \\
(2006)\end{array}$ & SATCOM & - & Customer loyalty & $\begin{array}{l}\text { The loyalty of customers was } \\
\text { significantly related to satisfaction with } \\
\text { complaint handling. }\end{array}$ \\
\hline Liao (2007) & SATCOM & - & RI & Consumer SATCOM impacted RI. \\
\hline $\begin{array}{l}\text { Santos; } \\
\text { Fernandes } \\
\text { (2008) }\end{array}$ & $\begin{array}{l}\text { SATCOM; trust; perceived } \\
\text { value }\end{array}$ & Switching costs & Loyalty (retention) & $\begin{array}{l}\text { SATCOM impacted on loyalty, but } \\
\text { switching costs did not moderate this } \\
\text { relationship. Trust was an important } \\
\text { antecedent of loyalty and switching } \\
\text { costs and perceived value also impacted } \\
\text { repurchase intention. }\end{array}$ \\
\hline $\begin{array}{l}\text { Pizzutti; } \\
\text { Fernandes } \\
\text { (2008) }\end{array}$ & $\begin{array}{l}\text { SATCOM; trust in } \\
\text { employees; trust in the } \\
\text { company; perceived value }\end{array}$ & - & Loyalty (retention) & $\begin{array}{l}\text { SATCOM impacts on RI; consumer } \\
\text { trust in the company and perceived } \\
\text { value also impact on RI. }\end{array}$ \\
\hline $\begin{array}{l}\text { Joireman et al. } \\
(2013)\end{array}$ & SATCOM & Inferred motive & Desire for reconciliation & $\begin{array}{l}\text { When inferred motive was positive (vs. } \\
\text { negative), desire for reconciliation lead } \\
\text { customers to choose more reparatory } \\
\text { than retaliatory behaviors. }\end{array}$ \\
\hline $\begin{array}{l}\text { Gohary et al. } \\
\text { (2016) }\end{array}$ & SATCOM & - & RI, customer loyalty & $\begin{array}{c}\text { SATCOM was positively related with } \\
\text { RI and consumer loyalty (behavioral } \\
\text { loyalty). }\end{array}$ \\
\hline $\begin{array}{l}\text { Gohary et al. } \\
\text { (2016) }\end{array}$ & SATCOM & - & Intention to reuse & $\begin{array}{c}\text { SATCOM was positively associated } \\
\text { with intention to reuse mobile banking } \\
\text { services. }\end{array}$ \\
\hline
\end{tabular}

Source: Elaborated by the authors

Concerning the role of RQ, research suggests two opposing views. In one view, a strong client-company relationship increases the negative impact of inadequate recovery in postcomplaint evaluations ("love becomes hate") (GRÉGOIRE et al., 2009). Following this perspective, Holloway et al. (2005) found that the effect of SATCOM on RI was in general higher for consumers with much experience in online purchasing than for those with little online purchasing experience. In the opposite view, a strong client-company relationship helps minimize the negative impact of inadequate recovery in post-complaint evaluations ("love is blind") (GRÉGOIRE; FISHER, 2006). We follow this logic because the literature favors the "love is blind" effect. For example, Pizzutti and Basso (2012) showed a buffering effect of the relationship strength in a lesser impact of SATCOM on trust for relational clients (versus transactional clients).

H1: As the RQ increases the relationship between SATCOM and RI will diminish.

\subsection{FAILURE-RELATED FACTORS: INFERRED MOTIVE AND FAILURE STABILITY}

Inferred motive (IM) is the extent to which "a customer believes a firm intended the double deviation to maximize its own interests and take advantage of the customer (negative motive), or help the customer (positive motive)" (JOIREMAN et al., 2013, p. 4). After a failure in recovery management, consumers who experienced transgressions will judge the responsible companies because judgment is an innate desire of people (VAN VAERENBERGH et al., 2014). This judgment could be positive (when the website explains and/or apologizes for the initial failure) or negative (when the website appears greedy or 
uncaring) (McCOLL-KENEDDY; SPARKS, 2003). Thus, whether the customer continues to buy from the website will depend on this valence (positive or negative) of judgment. Joireman et al.'s (2013) findings indicated that customers who inferred positive motives for the failure were more willing to reconcile with the company instead of seeking revenge.

Following this logic, when the IM regarding the initial failure is positive, the impact of SATCOM on RI will be weaker than when the inferred motive is negative. This effect will occur because customers who infer a positive reason for the company's actions believe that the website is trying to help them or will benefit them in the future (JOIREMAN et al., 2013).

$\mathrm{H} 2$ : As the positive inferred motive increases the relationship between SATCOM and RI will diminish.

\subsection{FAILURE STABILITY}

According to the literature, people facing failure scenarios form attributions to determine the cause of them (FOLKES, 1984). These attributions may occur in three dimensions: locus, controllability and stability (WEINER, 1980). Locus is related to whether the failure is located with the customer or the company (FOLKES, 1984). Controllability relates to the degree to which a party perceives a cause to be volitional or non-volitional, and stability is associated with whether the cause of the failure is something that is permanent (i.e., expected to remain stable) rather than temporary (i.e., varies over time) (HESS et al., 2003). In this paper, we focus on the stability dimension because the other dimensions are prerequisite for our research, that is, the company is the locus of the failure and controllability is implicitly considered in the inferred motive construct.

Linking stability with loyalty, Blodgett (1994) and Smith and Bolton (1998) showed that when consumers perceive the problem as stable, they have lower repurchase intentions from the same company than when consumers perceive the failure as not stable. This phenomenon occurs because when the cause of a failure is common and occurs every time, customers may perceive that the transgression will occur regardless of the company's preventive efforts (Hess et al., 2003). We propose that in online failure situations, the same pattern of results will occur: if consumers perceive the transgression as not stable, they may give the company a second chance, and if consumers perceive that the failure is common, they will avoid the company. Then, failure stability plays a moderating role in the relationship between SATCOM and RI: this relationship will be weaker when failure stability is lower. Hence, even when SATCOM is low, customers may buy from the same company again because the failure is only a one-time faux pas.

H3: As the failure stability decreases the relationship between SATCOM and RI will diminish.

\subsection{MARKETPLACE FACTORS: ECONOMIC VALUE AND ALTERNATIVE ATTRACTIVENESS}

When consumers buy online, they are unsure if the product displayed on the website is actually what they will receive (JIANG; ROSEMBLOOM, 2005), and this gap may influence their intentions to purchase products from the same e-retailer, even after service failures. Thus, efforts related to financial, temporal, behavioral and psychological resources play a role in determining consumers' intentions to return (GREWAL et al., 2003).

Keng and Ting (2009) found that the perceived economic value (EV) of blogs positively influences users' likelihood of using a blog. Likewise, Wu et al. (2014) show that e-shopping value (measured like economic value) is positively related to RI. Furthermore, price is a decisive factor in customers' intentions to purchase through e-commerce (JIANG; ROSEMBLOOM, 2005). However, little attention has been devoted to EV perceptions in 
BBR

14,3

e-retail contexts, wherein intense price competition exists (MATHWICK et al., 2001); the role of these perceptions after a failure/recovery situation has been particularly neglected. We propose that the impact of SATCOM on RI will be weaker when customers perceive higher EV than when they perceive lower EV.

H4: As the EV increases the relationship between SATCOM and RI will diminish.

\subsection{ALTERNATIVE ATTRACTIVENESS}

Attractiveness of alternatives (AA) refers to client perceptions of the extent to which viable competing alternatives are available in the marketplace (JONES et al., 2000, p 262). A lack of an attractive alternative may prompt customers to stay in their relationship with the supplier because the alternatives may be worse or nonexistent. However, when clients perceive that they could be satisfied with a company other than their actual provider, the current relationship may be dissolved (PING, 1993).

Jones et al. (2000) showed that the relationship between initial satisfaction and loyalty depends on the level of AA. Their findings showed that the relationship between satisfaction and loyalty is lower when consumers perceive few AA than when consumers perceive many AA.

Extending these results to failure situations in online retail, we propose that the relationship between SATCOM and RI may also depend on the level of AA. The rationale for this moderation is that if clients are unaware of alternative e-suppliers, they may stay in a relationship even when the recovery management is perceived as less than satisfactory, whereas when customers perceive the alternatives as more attractive, the relationship between SATCOM and RI will be stronger (i.e., customers are more likely to stay with the company when their satisfaction is high).

H5: As the AA decreases, the relationship between SATCOM and RI will diminish.

\section{METHOD}

To test our hypotheses, we conducted an online survey with North American online shoppers $(\mathrm{N}=500)$. Data were collected through Mechanical Turk from Amazon and operationalized by Qualtrics.

Before the survey, we conducted a pretest of the questionnaire $(\mathrm{N}=50)$, as a result of which some changes were made. The final data were collected in November 2013. Respondents who properly completed the questionnaire were rewarded with USD 0.80 . To participate in the survey, respondents should have had a failure after an online shopping experience over the last 6 months, they should have complained to the website, and these companies should have made some recovery effort to address their complaints. If the respondent had not experienced all these situations, he/she did not respond to the survey. The respondents answered the questionnaire by thinking about a specific failure and recovery process undertaken by the online retailer in question. We eliminated 75 cases due to incomplete questionnaires, and outliers. Our final sample included 425 cases. To avoid common method bias, we followed Podsakoff et al.'s suggestions (2003). Specifically, we separated questionnaire blocks, adopted different scale types, left distance between the independent and dependent variables, communicated the anonymity of the responses to the respondents, and avoided the use of vague terms or jargon.

Measures. All scales were seven-point Likert scales, except trust that was a seven-point differential semantic scale. Table 2 presents all the items with their factor loadings. 


\section{RESULTS}

Data were analyzed using the Statistical Package for the Social Sciences (SPSS) 20.0, the PROCESS macro for SPSS, and SmartPLS 2.0 M3. Regarding to the sample profile, more than half were male (57\%), and the average respondent's age was 32 . Approximately $72 \%$ of the respondents had made purchases through e-commerce for more than 5 years. For $71 \%$ of the respondents, the failure had occurred within approximately 3 months, showing that all of the complaint episodes were reasonably recent and increasing the likelihood of reliable respondent reporting. Only 36 respondents had never purchased from the website prior to the failure experience. Ninety-one percent of the respondents who had purchased from the same website before the transgression considered their relationship with the e-retailer to be good (mean of 5.96 on a 7-point scale).

Confirmatory factor analysis (CFA). We ran the CFA with SmartPLS. The estimation method of partial least squares (PLS) was chosen because this method has greater statistical power and is less sensitive to small sample size (PREACHER et al., 2007) than others. Based on the factor loadings, one item of IM and one item of SATCOM were eliminated from the analysis because they had a factor loading lower than .5, and the elimination of both represented no theoretical loss for the respective construct. Table 2 presents the means and standard deviations, AVE, Cronbach's alpha and composite reliability reached after removing these three items.

Furthermore, we tested the discriminant validity of the variables (without these three items as well). We found all the variables to differ from each other because all of the AVE values were greater than the correlation square of the variables (Table 3).

Tests of Moderation. Because our moderators are continuous, we tested our hypotheses through moderated regression analysis (HOMBURG; FÜRST, 2005), using the PROCESS macro (for SPSS) created by Hayes (2013) and a bootstrapping procedure (bootstrap samples were 5,000 cases, as suggested by Hair et al. (2006).

Literature has emphasized the importance of restricting the number of predictors in moderation tests within a single regression model due to different reasons, including: (1) avoid Type II errors (i.e., failing to find existing interactions) (VILLA et al., 2003), (2) when the number of predictors are limited, the results may be more evident (COHEN, 1990). Then, we standardized the predictor variable by mean centering and then computed the interaction terms by taking the product of the mean-centered predictor variables (COHEN et al. 2013). Finally, we ran a series of regression analyses (SEIDERS et al. 2005) to specify each moderating effect proposed in the hypotheses and to control misleading results. It is worth noting that this PROCESS macro made controlling the effect of the other moderating variables possible, as they were considered co-variables in the regression analyses.

To analyze the bootstrapping procedure, Preacher et al. (2007) argue that if zero is not between the lower limit of the confidence interval (LLCI) and the upper limit of the confidence interval (ULCI), then the effect is significant.

Hypothesis 1 proposes that for customers with high RQ, the relationship between SATCOM and RI is less important than for customers with lower RQ. As shown in Table 4 , the interaction effect between RQ and SATCOM is significant for RI $(\boldsymbol{\beta}=-.10, \mathrm{t}=-3.53$; $\mathrm{p}<.001$, confidence interval of -.1625 to -.0464). Thus, H1 is accepted: for individuals with high RQ, the impact of SATCOM on RI is lower than for individuals with low RQ, showing that RQ partially explains the nonlinearity between SATCOM and RI. Although the effect of the interaction variable (RQ X SATCOM) is not expressive $(\boldsymbol{\beta}=|.10|)$, it might be considered satisfactory, as indicated by Aguinis et al. (2005). Additionally, RQ has a significant impact on RI: the higher the quality of the relationship of the individual with the website, the greater the intention to repurchase from the company. 
Table 2. Summary of factor loadings, means, standard deviations, AVE and reliability

\begin{tabular}{lcccccc}
\hline Questions & $\begin{array}{c}\text { Factor } \\
\text { loading }\end{array}$ & Mean $^{2}$ & SD & AVE & Cronbach's alpha & $\begin{array}{c}\text { Composite } \\
\text { reliability }\end{array}$ \\
\hline SATCOM $^{1}$ (Tax et al., 1998) & - & 5.03 & 2.11 & .99 & .99 & .99
\end{tabular}

I'm happy with how the website handled my complaint.

.994

.994

I'm pleased with the manner in which the complaint was dealt with.

Overall I'm not satisfied with the way the complaint was handled. ${ }^{3}$

RI (Tax et al., 1998)

Make purchases from this website again?

Do more business with this website in the future?

Consider this website as your first choice to buy other things?

Have a larger volume of business with this website in the future? RQ

Trust (Grégoire; Fisher, 2008)

...very undependable/...very dependable

...very incompetent/...very competente

...of very low integrity/...of very high integrity

...very unresponsive to customers/...very responsive to customers

Commitment (Grégoire; Fisher, 2008)

I was very committed to my relationship with this website.

The relationship was something I intended to maintain for a long time.

I put the efforts into maintaining this relationship.

Satisfaction De Wulf, et al. (2001)

I was satisfied with my relationship with this website.

My relationship with this website was quite good.

I was happy with the effort this website was making towards consumers like me.

IM (Joireman et al., 2013)

...had bad intentions/...had good intentions

...intended to take advantage of me/...did not intend to take advantage of $\mathrm{me}^{* 3}$

...was primarily motivated by its own interest/...was primarily motivated by my interest

...tried to abuse me/... did not try to abuse me

EV (Mathwick et al., 2001)

The products from this website have good economic value.

Overall, I'm happy with the prices of this website.

The prices of the product(s) I purchased from this website are too high, given the quality of the merchandise.

AA (Jones et al., 2000)

If I needed to change website, there are other good websites to choose from.

I would probably be happy with the products and services of another website.

Compared to the website that I had that problem, there are other websites with which I would probably be equally or more satisfied.

Compared to the website that I had that problem, there are not very many other websites with whom I could be satisfied. ${ }^{1}$

FS (Boldgett, 1994)

This type of thing probably happens all the time with this website.

This website hardly ever makes mistakes.

Note: ${ }^{1}$ all items were measured on a 7 -point scale $\left(1=\right.$ Strongly Disagree and 7 = Strongly agree). ${ }^{2}$ Mean, SD, AVE, Alpha and Composite Reliability are the ones after removing the items. ${ }^{3}$ Items removed from the analysis.

Source: Elaborated by the authors
.451

5.16

.972

.968

.970

.903

.933

.936

.922

.867

.931

.927

.825

.970

.968

.961

.882

.063$$
\text { - } 947
$$

.840

.896

$\begin{array}{lllll}- & 3.30 & 1.38 & .75 & .68\end{array}$


Table 3. Discriminant validity of the latent variables

\begin{tabular}{|c|c|c|c|c|c|c|c|}
\hline & MI & AA & FS & RI & RQ & SATCOM & $\mathrm{EV}$ \\
\hline MI & 0,8042 & & & & & & \\
\hline AA & 0,0938 & 0,7126 & & & & & \\
\hline FS & 0,2100 & 0,0631 & 0,7459 & & & & \\
\hline RI & 0,4384 & 0,2642 & 0,2223 & 0,9089 & & & \\
\hline RQ & 0,2433 & 0,0429 & 0,2129 & 0,3268 & 0,8028 & & \\
\hline SATCOM & 0,5635 & 0,1566 & 0,1743 & 0,5725 & 0,1665 & 0,9875 & \\
\hline EV & 0,2076 & 0,0303 & 0,2036 & 0,2346 & 0,3084 & 0,1169 & 0,6984 \\
\hline
\end{tabular}

Note: The diagonal elements represent the AVE of the latent variables. Other elements represent the square of the correlation among the latent variables. SATCOM = satisfaction with complaint handling; RI = repurchase intention; RQ = relationship quality; IM = inferred motive; $\mathrm{EV}=$ economic value; $\mathrm{AA}=$ attractiveness of alternatives; $\mathrm{FS}$ = failure stability.

Source: Elaborated by the authors

Hypothesis 2 proposes that for customers who infer a positive reason for the initial perceived failure, the relationship between SATCOM and RI will be lower than for those individuals who perceive a negative reason. As shown in Table 4, the interaction effect between the variables inferred motive (IM) and SATCOM is significant $(\boldsymbol{\beta}=-.04, \mathrm{t}=-2.00 \mathrm{p}$ $<.01$, confidence interval of -.0786 to -.0007) for RI, confirming H2. Thus, when individuals tend to infer positive (negative) reasons for failures in the purchase experience, the effect of SATCOM on RI is smaller (larger). Hypothesis 3 proposes that the failure stability (FS) moderates the relationship between SATCOM and RI such that this relationship is weaker for customers who infer low stability than for those who infer higher FS. As shown in Table 4 , the interaction effect between the variables SF and SATCOM on RI is significant $(\boldsymbol{\beta}=$ $.06, \mathrm{t}=3.01, \mathrm{p}<.001$, confidence interval of .0197 to .0931 ), confirming H3.

Hypothesis 4 proposes that for customers with a high perception of EV, the relationship between SATCOM and RI is lower than for individuals with a lower EV perception. As shown in Table 4, the interaction effect between the variables EV and SATCOM is significant $(\boldsymbol{\beta}=-.06, \mathrm{t}=-2.34, \mathrm{p}<.05$, confidence interval of -.1044 to -.0091$)$ on repurchase intention, confirming H4.

Finally, hypothesis 5 proposes that for customers who perceive less AA, the relationship between SATCOM and RI is weaker than for customers who perceive the alternatives as more attractive. According to Table 4, the interaction effect between SATCOM and AA is significant on RI $(\boldsymbol{\beta}=.10, \mathrm{t}=4.99, \mathrm{p}<.001$, confidence interval of .0612 to .1412$)$, confirming H5. Moreover, the AA has a direct impact $(\boldsymbol{\beta}=-.32, \mathrm{p}<.001, \mathrm{t}=-7.4$, confidence interval of -.4121 to -.2402) on repurchase intention; that is, the lower the attractiveness of alternatives is, the greater the repurchase intention is.

\section{CONCLUSION}

In response to calls for deeper insight into factors that may moderate the satisfactionrepurchase relationship (e.g., VAN VAERENBERGH et al., 2014), this research presents and tests a conceptual framework that helps to explain why online shoppers who are dissatisfied with a company's recovery management are willing to buy from the same company again.

Despite the large amount of research showing that the conversion of initial satisfaction into repurchase is moderated by various factors, far less attention has been paid to final satisfaction or satisfaction following a company's failure and recovery process. One exception is Holloway et al . (2005) work, which explored the role of online purchase experiences in this relationship. To address this gap, the aim of this paper is to investigate factors that affect the relationship between SATCOM and RI in e-retail.

We extend Holloway et al. (2005) by testing several relational aspects between the client and the website in question (i.e., prior satisfaction, trust and commitment) rather than simply 
BBR

14,3

Table 4. Test of the hypotheses

Dependent variable

RI

\begin{tabular}{|c|c|c|c|c|}
\hline Relationship quality (RQ) $^{1}$ & $\mathrm{R}^{2}=.70$ & LLCI & ULCI & Hypothesis \\
\hline Main effect & & $\beta$ (t-value) & & \\
\hline RQ & $.29(3.72)^{* *}$ & .1386 & .4491 & \\
\hline SATCOM & $.40(8.00)^{* *}$ & .2986 & .4933 & \\
\hline \multicolumn{5}{|l|}{ Interaction effect } \\
\hline RQ x SATCOM & $-.10(-3.53)^{* *}$ & -.1625 & -.0464 & $\mathrm{H} 1$ is accepted \\
\hline Inferred motive (IM) & $\mathrm{R}^{2}=.71$ & & & \\
\hline \multicolumn{5}{|l|}{ Main effect } \\
\hline IM & $.04(.60)$ & -.0901 & .1695 & \\
\hline SATCOM & $.43(7.44)^{* *}$ & .3136 & .5387 & \\
\hline \multicolumn{5}{|l|}{ Interaction effect } \\
\hline IM x SATCOM & $-.04(-2.00)^{*}$ & -.0786 & -.0007 & $\mathrm{H} 2$ is accepted \\
\hline Failure Stability (FS) & $\mathrm{R}^{2}=.71$ & & & \\
\hline \multicolumn{5}{|l|}{ Main effect } \\
\hline FS & $-.04(-.94)$ & -.1330 & .0465 & \\
\hline SATCOM & $.44(7.99)^{* *}$ & .3352 & .5536 & \\
\hline \multicolumn{5}{|l|}{ Interaction effect } \\
\hline FS x SATCOM & $.06(3.01)^{* *}$ & .0197 & .0931 & $\mathrm{H} 3$ is accepted \\
\hline Economic value (EV) & $\mathrm{R}^{2}=.71$ & & & \\
\hline \multicolumn{5}{|l|}{ Main effect } \\
\hline EV & $.14(2.35)^{*}$ & .0234 & .2605 & \\
\hline SATCOM & $.45(8.44)^{* *}$ & .3499 & .5624 & \\
\hline \multicolumn{5}{|l|}{ Interaction effect } \\
\hline EV x SATCOM & $-.06(-2.34)^{*}$ & -.1044 & -.0091 & H4 is accepted \\
\hline Attractive of alternatives (AA) & $\mathrm{R}^{2}=.73$ & & & \\
\hline \multicolumn{5}{|l|}{ Main effect } \\
\hline $\mathrm{AA}$ & $-.32(-7.45)^{* *}$ & -.4121 & -.2402 & \\
\hline SATCOM & $.41(7.08)^{* *}$ & .3003 & .5310 & \\
\hline \multicolumn{5}{|l|}{ Interaction effect } \\
\hline AA x SATCOM & $.10(4.99)^{* *}$ & .0612 & .1412 & H5 is accepted \\
\hline
\end{tabular}

${ }^{*} \mathrm{p}<.05 ;{ }^{* *} \mathrm{p}<.01$

1 The RQ moderation test was performed with a sample of 389 cases, because we removed from final sample $(\mathrm{N}=425), 36$ cases that had not previously purchased from the website. For the other variables, the test of moderation was performed with the total sample $(\mathrm{N}=433)$.

Source: Elaborated by the authors

the frequency of and amount of spending in online purchase experiences as a whole by including other moderators to investigate the phenomenon in a more comprehensive way, by using a sample of nonstudents and focusing on real purchases instead of fictional scenarios and by not dichotomizing the moderating variables. Moreover, we corroborate the idea that "love is blind": a strong client-company relationship helps minimize the negative impact of inadequate recovery in future behavioral intentions (Grégoire and Fisher, 2006). The "love is blind" effect is also supported by the interpretation bias literature, which states that even when individuals receive and understand information, the effect of interpretation bias may exist because clients with a high level of relationship with a company may reduce their perceptions of severity and unfairness upon experiencing a service recovery to maintain consistency between their past and current perceptions. 
Regarding the moderating roles of the failure-related variables (inferred motive and failure stability), the findings reveal that the more positive the motive inferred for a failure by a customer, the weaker the relationship between satisfaction with complaint handling and repurchase intention. This logic is consistent with the results found by Joireman et al. (2013): when the inferred motive (the cause of the initial failure) is perceived as positive, the customer has higher intentions of reconciliation with the company that caused the failure. Likewise, the less stable the failure is in the eyes of the complaining customer, the weaker the relationship is between SATCOM and RI. Therefore, even at low levels of SATCOM, if the failure is not expected to recur over time (i.e., is less stable), then the customer will have higher intentions to repurchase from the website.

In relation to the marketplace variables, the results indicate that the greater the economic value of the site and the less attractive the competitors as perceived by the customer, the weaker the relationship is between SATCOM and RI. We show that economic value and competiveness perceptions are important factors for customers in deciding whether to give companies a second chance after double deviation situations.

\subsection{THEORETICAL IMPLICATIONS}

In online retail loyalty has important implications for business, and presents a challenge for websites due to distinct factors, such as the high number of competitors operating in this type of retail (GREWAL et al., 2010) and customer empowerment (KUMAR et al ., 2013). Despite the relevance of repurchase in e-retails, this topic has received little attention to date in the literature (KUMAR et al., 2013).

This research investigates a relevant and little-explored question in the context of e-commerce: why SATCOM does not necessary lead to RI for e-shoppers? Based on our findings, some reasons for a weaker relationship between SATCOM and RI are as follows: customers have good prior relationships with the website (i.e., they felt satisfied with, committed to and trusting toward the website before the occurrence of the failure); they infer positive motives on the part of the company regarding the initial failure; they perceive the failure as relatively less stable; and they perceive good economic value related to the website and the competition as less attractive. Therefore, this research has contributed to the theoretical field that involves failures and recovery attempts in online shopping by explaining the nonlinearity between SATCOM and RI. Moreover, we conducted this study by testing a set of moderating variables, as recommended by Kumar et al. (2013).

By testing the moderating role of RQ in the effect of SATCOM on RI, we extend the results of Grégoire et al. (2009). These authors showed that the desire for revenge and sense of betrayal decrease for continuing consumers who receive a recovery attempt, whereas for consumers with weak relationships with the company, only high compensation produces the same result. Our study indicates that client-company RQ partially explains the nonlinearity of the relationship between SATCOM and RI in online retail. This relationship is reduced when there is a stronger relationship between the customer and the transgressive company. Hence, relational clients seem to build behavioral intentions, based on aspects in addition to satisfaction, such as their history and prior experiences with the company, whereas a satisfactory recovery is a more vital element in enhancing repurchase intentions for transactional clients (i.e., clients who perceive low relationship quality).

Another theoretical implication of our study is the finding that the motive inferred by the customer may help explain the nonlinearity of the relationship between SATCOM and RI. Our study extends Joireman et al.'s (2013) work, which found that the inferred motive explains why customer's desire reconciliation rather than revenge following a double deviation by testing the moderating role of IM on the relation between SATCOM 
BBR

and RI through a survey using actual data on online shopping experiences applied to the e-commerce context.

We also highlight the investigation of the effects of failure attributions in the e-retail context. Smith and Bolton (1998), for example, explored the direct impact of failure stability on patronage intentions. However, to the best of our knowledge, the present study is the first to explore the moderating role of failure stability attributions in the relationship between SATCOM and RI.

Additionally, we listened to the calls of Wu et al. (2014) for more research related to economic value. We showed that customers' perceptions of positive returns on their investments (their perceptions of the selling price given the quality of the merchandise) act as a moderator in the relationship between SATCOM and RI in online retail.

Finally, we extend the results of Jones et al. (2000) by exploring the relationship between satisfaction after a failure and repurchase in online retail. Our findings indicate that the influence of SATCOM on RI is weaker for customers who perceive few attractive alternatives than it is for customers who perceive many attractive alternatives. Hence, a scenario with low competition is favorable for a nonlinear relationship between SATCOM and RI.

\subsection{MANAGERIAL IMPLICATIONS}

This study provides important contributions for marketers who work with online retail by proffering explanations for why customers may give a second chance to the company after a poor service recovery. Because prior experiences with the website play an important role when a company fails to solve customers' problems with its website, we suggest that companies should systematically measure and control customers' satisfaction, trust and commitment during their transactions. To manage these variables, companies could invite customers to fill out surveys related to these dimensions after their shopping experience. According to the results, for customers who provide low ratings on some of these dimensions, corrective actions (such as bonuses and apologies) should be taken. To motivate customer participation in the survey, credits on purchases or even more consistent rewards may be distributed. This may help companies provide an enjoyable and seamless shopping experience to customers and develop an open and transparent relationship with them.

We also suggest that websites act in a transparent way with customers throughout the buying process to promote customer trust in the company. For example, the company can interact with customers through chat or online communities to answer questions about pricing, products, shopping. shipping and can send follow-up emails if necessary. These actions should activate consumers' engagement, which may strengthen their commitment to the website.

Moreover, we show that the motive for the initial failure that is inferred by the customer is important in the maintenance of the customer's repurchase intentions. In other words, the website should signal that it truly wants to help the customer despite the failure. This signal or explanation can be provided by trained employees who are responsible for managing complaints. These employees could identify the transgression, address it, and monitor customers' final evaluations by contacting them after the incident is resolved.

Another managerial contribution is related to failure attributions. Failures with stable causes may have negative impacts on RI because they lead customers to expect the same outcome in the future. Therefore, managers could promise to customers by e-mail, letter, or a phone call that the problem will not recur to restore trust. However, to make this promise, it is necessary to permanently solve the internal problems that generated the failure. Thus, websites should monitor customers' shopping and track complaints on websites and its own 
fan pages to determine whether there is public demand against the company. If there are many complaints about the company, it may appear that failures are stable to that company, which is not recommended.

Regarding customers' economic value perceptions, websites should be aware of the adopted pricing strategy for the marketed products and services. Our findings indicate that the influence of post-recovery satisfaction on repurchase intentions is weaker for individuals who perceive higher returns on their investments than for individuals who perceive lower economic value related to e-retail. In other words, even after poor recovery management, customers may repurchase from a company that offers them good deals. This result shows the importance of companies maintaining offers with attractive selling prices, given the quality of the products and services. The logic of this relationship is that customers evaluate whether their net gain from acquiring the product and/or service is worthwhile. Therefore, websites should monitor the prices of their e-commerce competitors and communicate their selling prices in an attractive way, or recommend the products with best prices in relation to their competitors, and provide tailored offers to customers. These strategies may help the company retain customers, even in situations involving failure experiences.

Finally, companies should be aware of the attractiveness of alternatives in e-commerce. We show that customers will consider how well the company has managed their complaints, particularly when they perceive that there are other attractive alternatives in the market. Hence, especially in the context of high competition, websites should manage their competitive advantages and handle complaints satisfactorily because customers' satisfaction with recovery management is key in determining whether they give companies second chances.

\subsection{LIMITATIONS AND SUGGESTIONS FOR FUTURE STUDIES}

This study's limitations should be kept in mind when considering its contributions. This paper used a cross-sectional approach based on a nonprobabilistic sample composed of people who had purchased from and complained to a website when the data collection occurred. Because we used a cross-sectional design based on retrospective reports, recall bias could have influenced the results. Furthermore, the study explored B2C transactions and may not easily generalize to other transaction types (e.g., B2B and C2C).

Future research could also examine other variables that may help explain the nonlinearity of the relationship between SATCOM and RI. Aksoy et al.'s (2013) findings reveal that the impact of satisfaction on loyalty may depend on cultural differences because this relationship is stronger in countries characterized by self-expressionist values than in cultures dominated by high survivalist values. In addition, the moderating role of loyalty programs (VERHOEF, 2003) and company reputation (EISENBEISS et al., 2014) could be explored. Note that we do not explore switching costs because we consider online retail in general an environment with low exit barriers in the eyes of customers. Nevertheless, new research could examine the role of switching costs as moderators of the relationship between SATCOM and RI in specific types of e-retail in which switching costs are apparently higher, such as online banking and the brokerage industry.

\section{REFERENCES}

AGUINIS, H.et al. Effect size and power in assessing moderating effects of categorical variables using multiple regression: a 30-year review. Journal of Applied Psychology, v. 90, n. 1, p. 94, 2005.

AKSOY, L.et al. A cross-national investigation of the satisfaction and loyalty linkage for mobile telecommunications services across eight countries. Journal of Interactive Marketing, v. 27, n. 1, p. 74-82, 2013. 
ANDERSON, Rolph E.; SRINIVASAN, Srini S. E-satisfaction and e-loyalty: a contingency framework. Psychology and Marketing, v. 20, n. 2, p. 123-138, 2003.

ANDREASEN, Alan R. A taxonomy of consumer satisfaction/dissatisfaction measures. Journal of Consumer Affairs, v. 11, n. 2, p. 11-24, 1977.

BLODGETT, Jeffrey G. The effects of perceived justice on complainants' repatronage intentions and negative word-of-mouth behavior. Journal of Consumer Satisfaction, Dissatisfaction and Complaining Behavior, v. 7, n. 1.14, 1994.

COHEN, Jacob. Things I have learned (so far). American psychologist, v. 45, n. 12, p. 1304, 1990.

COHEN, J.; Cohen, P.; WEST, S. G.; AIKEN, L. S. Applied multiple regression/correlation analysis for the behavioral sciences. Routledge, 2013.

CONLON, Donald E.; MURRAY, Noel M. Customer perceptions of corporate responses to product complaints: The role of explanations. Academy of management journal, v. 39, n. 4, p. 1040-1056, 1996.

DAVIDOW, Moshe. The bottom line impact of organizational responses to customer complaints. Journal of hospitality \& tourism research, v. 24, n. 4, p. 473-490, 2000.

DE WULF, Kristof; ODEKERKEN-SCHRÖDER, Gaby; IACOBUCCI, Dawn. Investments in consumer relationships: a cross-country and cross-industry exploration. Journal of marketing, v. 65, n. 4, p. 33-50, 2001.

DUBE, Laurette; MAUTE, Manfred F. Defensive strategies for managing satisfaction and loyalty in the service industry. Psychology \& Marketing, v. 15, n. 8, p. 775-791, 1998.

EISENBEISS, Maik; et al. Nonlinear and asymmetric returns on customer satisfaction: do they vary across situations and consumers?. Journal of the Academy of Marketing Science, v. 42, n. 3, p. 242-263, 2014.

EMARKETER.COM. Worldwide Retail Ecommerce Sales: eMarketer's Updated Estimates and Forecast Through 2019 - eMarketer. [online] Available at: http://www.emarketer.com/corporate/coverage\#/ results/1273?look [Accessed 07 Jan. 2016], 2016.

FOLKES, Valerie S. Consumer reactions to product failure: An attributional approach. Journal of consumer research, p. 398-409, 1984.

GILLY, Mary C. Postcomplaint processes: from organizational response to repurchase behavior. Journal of Consumer Affairs, v. 21, n. 2, p. 293-213, 1987.

GILLY, Mary C.; GELB, Betsy D. Post-purchase consumer processes and the complaining consumer. Journal of Consumer Research, p. 323-328, 1982.

GOHARY, Ali. et al. Understanding effects of co-creation on cognitive, affective and behavioral evaluations in service recovery: an ethnocultural analysis. Journal of Retailing and Consumer Services, v. 31, p. 182-198, 2016.

GOHARY, Ali; HAMZELU, Bahman; ALIZADEH, Hamid. Please explain why it happened! How perceived justice and customer involvement affect post co-recovery evaluations: a study of Iranian online shoppers. Journal of Retailing and Consumer Services, v. 31, p. 127-142, 2016.

GRÉGOIRE, Yany; FISHER, Robert J. The effects of relationship quality on customer retaliation. Marketing Letters, v. 17, n. 1, p. 31-46, 2006.

; FISHER, Robert J. Customer betrayal and retaliation: when your best customers become your worst enemies. Journal of the Academy of Marketing Science, v. 36, n. 2, p. 247-261, 2008.

; TRIPP, Thomas M.; LEGOUX, Renaud. When customer love turns into lasting hate: the effects of relationship strength and time on customer revenge and avoidance. Journal of Marketing, v. 73, n. 6, p. 18-32, 2009.

GREWAL, Dhruv et al. The Internet and the price-value-loyalty chain. Journal of Business Research, v. 56, n. 5, p. 391-398, 2003.

GREWAL, Dhruv et al. Strategic online and offline retail pricing: a review and research agenda. Journal of Interactive Marketing, v. 24, n. 2, p. 138-154, 2010.

GUMESSON, Evert. The new marketing-Developing long-terme, Interactive relationship. Long Range Planning, v. 20, n. 4, p. 10-20, 1987.

HAIR, Joseph F.et al. Multivariate data analysis. Upper Saddle River, NJ: Pearson Prentice Hall, 2006.

HARRIS, Katherine E.; MOHR, L. A.; BERNHARDT, K. L. Consumer responses to service recovery strategies: the moderating role of online versus offline environment. Journal of Business Research, v. 59, n. 4, p. 425-431, 2006. 
HAYES, Andrew F. Introduction to mediation, moderation, and conditional process analysis: A regression-based approach. Guilford Press, 2013.

HESS JR, Ronald L. The impact of firm reputation and failure severity on customers' responses to service failures. Journal of Services Marketing, v. 22, n. 5, p. 385-398, 2008.

HESS, Ronald L.; GANESAN, Shankar; KLEIN, Noreen M. Service failure and recovery: the impact of relationship factors on customer satisfaction. Journal of the Academy of Marketing Science, v. 31, n. 2, p. 127-145, 2003.

HOLLOWAY, Betsy B.; BEATTY, Sharon E. Service failure in online retailing a recovery opportunity. Journal of service research, v. 6, n. 1, p. 92-105, 2003.

HOLLOWAY, Betsy Bugg; WANG, Sijun; PARISH, Janet Turner. The role of cumulative online purchasing experience in service recovery management. Journal of Interactive Marketing, v. 19, n. 3, p. 54-66, 2005.

HOLLOWAY, Betsy Bugg; WANG, Sijun. 6. Service failure and recovery: implications for relationship marketing. Handbook on Research in Relationship Marketing, p. 123, 2015.

HOMBURG, Christian; FÜRST, Andreas. How organizational complaint handling drives customer loyalty: an analysis of the mechanistic and the organic approach. Journal of Marketing, v. 69, n. 3, p. 95-114, 2005.

HOMBURG, Christian; GIERING, Annette. Personal characteristics as moderators of the relationship between customer satisfaction and loyalty_an empirical analysis. Psychology \& Marketing, v. 18, n. 1, p. 43-66, 2001.

JIANG, Pingjun; ROSENBLOOM, Bert. Customer intention to return online: price perception, attribute-level performance, and satisfaction unfolding over time. European Journal of Marketing, v. 39, n. 1/2, p. 150-174, 2005.

JOIREMAN, Jeff. et al. When do customers offer firms a "second chance" following a double deviation? The impact of inferred firm motives on customer revenge and reconciliation. Journal of Retailing, v. 89, n. 3, p. 315-337, 2013.

JONES, Michael A.; MOTHERSBAUGH, David L.; BEATTY, Sharon E. Switching barriers and repurchase intentions in services. Journal of retailing, v. 76, n. 2, p. 259-274, 2000.

JONES, Michael A.; MOTHERSBAUGH, David L.; BEATTY, Sharon E. Why customers stay: measuring the underlying dimensions of services switching costs and managing their differential strategic outcomes. Journal of business research, v. 55, n. 6, p. 441-450, 2002.

KAU, Ah-Keng; LOH, Wan-Yiun Elizabeth. The effects of service recovery on consumer satisfaction: a comparison between complainants and non-complainants. Journal of Services Marketing, v. 20, n. 2, p. 101-111, 2006.

KEATING, Byron W.et al. Mediating role of relationship quality in online services. Journal of Computer Information Systems, v. 52, n. 2, p. 33-41, 2011.

KENG, Ching-Jui; TING, Hui-Ying. The acceptance of blogs: using a customer experiential value perspective. Internet Research, v. 19, n. 5, p. 479-495, 2009.

KIM, Taegoo Terry; KIM, Woo Gon; KIM, Hong-Bumm. The effects of perceived justice on recovery satisfaction, trust, word-of-mouth, and revisit intention in upscale hotels. Tourism Management, v. 30, n. 1, p. 51-62, 2009.

KUMAR, V.; DALLA POZZA, Ilaria; GANESH, Jaishankar. Revisiting the satisfaction-loyalty relationship: empirical generalizations and directions for future research. Journal of Retailing, v. 89, n. 3, p. 246-262, 2013.

LIAO, Hui. Do it right this time: the role of employee service recovery performance in customer-perceived justice and customer loyalty after service failures. Journal of applied psychology, v. 92, n. 2, p. 475, 2007.

MARTIN, Charles L.; SMART, Denise T. Consumer experiences calling toll-free corporate hotlines. Journal of Business Communication, v. 31, n. 3, p. 195-212, 1994.

MATHWICK, Charla; MALHOTRA, Naresh; RIGDON, Edward. Experiential value: conceptualization, measurement and application in the catalog and Internet shopping environment. Journal of retailing, $\mathrm{V}$. 77, n. 1, p. 39-56, 2001.

MATTILA, Anna S. The effectiveness of service recovery in a multi-industry setting. Journal of Services Marketing, v. 15, n. 7, p. 583-596, 2001. 
BBR

14,3

MATTILA, Anna S.; MOUNT, Daniel J. The impact of selected customer characteristics and response time on e-complaint satisfaction and return intent. International Journal of Hospitality Management, v. 22, n. 2, p. 135-145, 2003.

MATTILA, Anna S. The impact of service failures on customer loyalty: The moderating role of affective commitment. International Journal of Service Industry Management, v. 15, n. 2, p. 134-149, 2004.

MCCOLL-KENNEDY, Janet R.; DAUS, Catherine S.; SPARKS, Beverley A. The role of gender in reactions to service failure and recovery. Journal of Service Research, v. 6, n. 1, p. 66-82, 2003.

MCCOLL-KENNEDY, Janet R.; SPARKS, Beverley A. Application of fairness theory to service failures and service recovery. Journal of service research, v. 5, n. 3, p. 251-266, 2003.

ORSINGHER, Chiara; VALENTINI, Sara; DE ANGELIS, Matteo. A meta-analysis of satisfaction with complaint handling in services. Journal of the Academy of Marketing Science, v. 38, n. 2, p. 169-186, 2010.

PING, Robert A. The effects of satisfaction and structural constraints on retailer exiting, voice, loyalty, opportunism, and neglect. Journal of retailing, v. 69, n. 3, p. 320-352, 1993.

PIZZUTTI, Cristiane; FERNANDES, Daniel Von der Heyde. Antecedents and consequences of consumer trust in the context of service recovery. BAR-Brazilian Administration Review, v. 5, n. 3, p. 225-244, 2008.

PIZZUTTI, Cristiane; FERNANDES, Daniel. Effect of recovery efforts on consumer trust and loyalty in e-tail: A contingency model. International Journal of Electronic Commerce, v. 14, n. 4, p. 127-160, 2010.

PIZZUTTI, Cristiane; FERNANDES, Daniel Von der Heyde. A recuperação de serviços como ferramenta de relacionamento e seu impacto na confiança e lealdade dos clientes. Revista de Administração de Empresas, v. 48, n. 1, p. 10-24, 2008.

PIZZUTTI, Cristiane; BASSO, Kenny. Do ongoing relationships buffer the effects of service recovery on customers' trust and loyalty?. International Journal of Bank Marketing, v. 30, n. 3, p. 168-192, 2012.

PODSAKOFF, Philip M.et al. Common method biases in behavioral research: a critical review of the literature and recommended remedies. Journal of applied psychology, v. 88, n. 5, p. 879, 2003.

PREACHER, Kristopher J.; RUCKER, Derek D.; HAYES, Andrew F. Addressing moderated mediation hypotheses: Theory, methods, and prescriptions. Multivariate behavioral research, v. 42, n. 1, p. 185-227, 2007.

SEIDERS, Kathleen. et al. Do satisfied customers buy more? Examining moderating influences in a retailing context. Journal of Marketing, v. 69, n. 4, p. 26-43, 2005.

SIRDESHMUKH, Deepak; SINGH, Jagdip; SABOL, Barry. Consumer trust, value, and loyalty in relational exchanges. Journal of marketing, v. 66, n. 1, p. 15-37, 2002.

SMITH, Amy K.; BOLTON, Ruth N. An experimental investigation of customer reactions to service failure and recovery encounters paradox or peril?. Journal of service research, v. 1, n. 1, p. 65-81, 1998.

SPRENG, Richard A.; HARRELL, Gilbert D.; MACKOY, Robert D. Service recovery: impact on satisfaction and intentions. Journal of Services Marketing, v. 9, n. 1, p. 15-23, 1995.

SUN, Heshan. Sellers' Trust and Continued Use of Online Marketplaces. Journal of the Association for Information Systems, v. 11, n. 4, p. 182, 2010.

TAX, Stephen S.; BROWN, Stephen W.; CHANDRASHEKARAN, Murali. Customer evaluations of service complaint experiences: implications for relationship marketing. The Journal of Marketing, p. 60-76, 1998.

VAN VAERENBERGH, Yves. et al. A meta-analysis of relationships linking service failure attributions to customer outcomes. Journal of Service Research, p. 1094670514538321, 2014.

VERHOEF, Peter C. Understanding the effect of customer relationship management efforts on customer retention and customer share development. Journal of marketing, v. 67, n. 4, p. 30-45, 2003.

VILLA, Jennifer R. et al. Problems with detecting moderators in leadership research using moderated multiple regression. The Leadership Quarterly, v. 14, n. 1, p. 3-23, 2003.

WANG, Cheng; HARRIS, Jennifer; PATTERSON, Paul G. Customer choice of self-service technology: the roles of situational influences and past experience. Journal of Service Management, v. 23, n. 1, p. 54-78, 2012.

WEBSTER, Cynthia; SUNDARAM, D. S. Service consumption criticality in failure recovery. Journal of Business Research, v. 41, n. 2, p. 153-159, 1998. 
WEINER, Bernard. A cognitive (attribution)-emotion-action model of motivated behavior: An analysis of judgments of help-giving. Journal of personality and social psychology, v. 39, n. 2, p. 186, 1980.

WU, Lei-Yu. et al Perceived value, transaction cost, and repurchase-intention in online shopping: A relational exchange perspective. Journal of Business Research, v. 67, n. 1, p. 2768-2776, 2014. 